\title{
Sempozyum Tanıtımı
}

\section{Zeynep KAYA*}

\section{“İslâm Tarihinin İlk Asrında Diyarbakır ve Çevresi” Sempozyumu ve XI. İslam Tarihi Anabilim Dalları Koordinasyon Toplantısı}

Diyarbakır Valiliği, İslâm Tarihçileri Derneği ve İlim Yayma Cemiyeti Diyarbakır Şubesi işbirliğiyle düzenlenen "İslâm Tarihinin İlk Asrında Diyarbakır ve Çevresi” konulu Sempozyum, 23 Mayıs tarihinde Diyarbakır'da Cahit Sıtkı Tarancı Kültür Merkezi Orhan Asena Sahnesinde gerçekleştirildi. Sempozyuma tebliğci ve müzakereci olarak yüzden fazla akademisyen, aralarında Diyarbakır Valisi Mustafa Cahit Kıraç, Devlet Eski Bakanı Prof. Dr. Mehmet Aydın’ın da bulunduğu çok sayıda bürokrat ve öğrenci de iştirak etti.

Sempozyum programı saygı duruşu ve İstiklâl marşının akabinde İlim Yayma Cemiyeti Diyarbakır Şube Başkanı Dr. Mustafa Sarıbıyık’’n açılış konuşmasıyla başladı. Program vesilesiyk le Diyarbakır'a gelen Türkiye İlâhiyat fakültelerinde görevli İslâm tarihi hocalarıyla Diyarbakır’ın tarihî ve kültürel değerlerini buluşturma arzusunu dile getiren Sarıbıyık, medyanın olumsuz tutumuna rağmen tüm dünyaya kendisini haykırmaya devam eden şehrin tevhit medeniyetine bir köprü olma özelliği taşıdığını belirtti.

İslâm Tarihçileri Derneği Başkanı Prof. Dr. Mehmet Şeker açılışta yaptığı konuşmasına Soma'da vefat eden maden işçilerini anarak başladı. Bereketli Hilal bölgesinin önemine vurgu yapan Şeker, Sempozyum'da bu Hilal'in bir parçası olan topraklarda makamları bulunan peygamı berlerden başlayarak nebiler şehri olan Diyarbakır'ın tarihi ile İslâm tarihinin ilk asrında bölgeye gelmiş olan sahabîlerin işleneceğini bildirdi.

Diyarbakır Valisi Mustafa Cahit Kıraç, tarih boyunca 33 medeniyete ev sahipliği yapan 13 bin yillık geçmişe sahip peygamberler şehrinde bu Sempozyumun düzenlenmesinden duyduğu memnuniyeti ifade ederek katılımcıları selamladı. Şehrin üzerindeki sis bulutlarının kalkmasında Sempozyumun büyük katkı sunacağını belirterek sürdürdüğü konuşmasında Kıraç, üç büyük dini kendisinde huzur ortamı içerisinde cem etmiş bu kadim kentin ışıltılı günlerine dönmek üzere önemli merhaleler kat ettiğini ifade etti. Vali Kıraç’ın konuşmasını müteakip Diyarbakır Valiliğince hazırlanan "Âlemleri Nur Eyғ ledi” adlı tanıtım klibinin gösterilmesinden sonra kürsüye Devlet Eski Bakanı Prof. Dr. Mehmet Aydin davet edildi.

Talebelik yıllarının bir kısmını geçirdiği Diyarbakır’a gelmiş olmaktan duyduğu memnuniyeti ifade eden Aydın, bir yüzyıllık sürede İslâm tarihinin ilk asrında olduğu kadar muvaffakiyet

\footnotetext{
* Marmara Üniversitesi Sosyal Bilimler Enstitüsü. Arş. Gör.,
} 
dolu bir başka asır bulunmadı̆̆ını belirterek bu dönemin evrensel medeniyetin inşâsındaki roa lünü vurguladı. Diyarbakır'da böyle bir organizasyonla bir araya gelmiş olmanın mesuliyetiyle kalıcı bir armağan bırakılması gerektiğini ifade eden Aydın, tüm İslâm dünyası gibi Diyarbakır’n da çalışılmaya muhtaç olduğunu söyledi. Açılış konuşmalarının nihayetinde Sempozyumun ilk oturumuna geçildi.

Prof. Dr. Mehmet Çelik'in başkanlığında gerçekleştirilen birinci oturumda Cezîre bölgesi ile özelde Diyarbakır'da makamı bulunan peygamberler ele alındı. "Peygamberler Tarihi Bakımından Cezîre” başlığıyla sempozyumun ilk tebliğini sunan Doç. Dr. Hüseyin Güneş, Şanlıurfa'da on üç, Diyarbakır'da on, Şırnak'da ise bir peygamberin yaşadığına inanıldığını; ancak bu rivayetlerin çoğunun İslâm tarihi kaynaklarınca desteklenmediğini belirtti. Bu peygamberlerden sadece Hz. İbrahim'in bölge ile ilişkisinin doğrulandığını açıklayan Güneş, Harran'da dünyaya gelen Hz. İbrahim'in babası tarafından Irak’a götürüldüğü ve ateşe de burada atıldığını bildirdi. Hz. Nuh’un gemisinin ise Cudi Dağı’na indiği hususunda şüphe bulunmadığını söyleyen Güneş, Cudi Dağı'nın Şırnak’ta bulunduğunu ifade etti. Otut rumun ikinci tebliğini "Peygamberler Tarihi Bakımından Diyarbakır" ismiyle sunan Prof. Dr. Abdurrahman Acar Diyarbakır'da Hüseyin Güneş’in de ifade ettiği üzere on peygamberin bulunduğunun söylendiğini belirterek konuşmasına başladı. Bunlardan Hz. Zülkifl ve Hz. Elyesa'nın Kurân-1 Kerîm'de ismi geçen peygamberler olduğunu bildiren Acar, Kurân-1 Kerîm'de ismi geçen 25 peygamberin tamamının metfun olduğu mekânların bilinmediğini ekledi. Bu noktada bir şehrin zikri geçen kabilden anlatılar vasıtasıyla kabirleri ve makamları bulunan peygamberleri içselleştirerek gündelik yaşama katmasının önemini vurgulayan Acar, şehrin kendisini tanımlarken de "Peygamberler Şehri” gibi manevi bir sıfat kullanmah nın önemi üzerinde durdu. Acar’ın tebliğini müteakip müzakerelerle hitama eren oturumdan sonra, kısa bir ara verildi.

Prof. Dr. Hüseyin Algül başkanlığında gerçekleştirilen ikinci oturumda Cezîre bölgesi ile Diyarbakır'ın Müslümanlar tarafından fethi ele alındı. Bu oturumda ilk olarak Prof. Dr. İsrafil Balcı Cezîre bölgesinin fethini anlattığ 1 tebliğini arz etti. Bölgeye ilerlemekte olan İslâm ordusundan çekinerek Heraklius'un toprakları boşaltmasını müteakip süratle ilerleyen İslâm fetihleriyle ilgili bilgi veren Balc1, Cezîre bölgesine ilk giren ordunun coğrafi sebepler de dikkate alındığında Irak tarafındaki ordu olması gerektiğini ifade ettikten sonra, Şam bölgesine yakın olan kısımların ise bu arazideki ordu tarafından ele geçirildiğini ekledi. Oturum Prof. Dr. Mehmet Azimli’nin “Diyarbakır Bölgesinin Müslümanlarca Fethi” başlıklı tebliğiyle devam etti. Sunumuna Cezire bölgesinin fethi ile ilgili yapılan araştırmalarda içerdiği ayrıntılı malumat nedeniyle Fütûhu'ş-Şam'dan yararlanıldığına, ancak Vâkıdî̀ye nispeti hususunda ciddi sıkıntılar bulunan bu eserin diğer kaynaklarla teyit edilmediği müddetçe kullanılmaması gerektiğine dikkat çekerek başlayan Azimli, İyâd b. Ğanm tarafından Diyarbakır'ın fethedilmesi ile ilgili bilgi verdi. Şam tarafından bölgeye giren ordunun fazla zorlanmadan bölgeyi ele geçirdiğini ve Ruha anlaşmasının şartlarının Diyarbakır’a da uygulandığını ifade eden Balcı'nın sunumundan sonra tebliğlerin müzakereleri yapılarak Cuma namazı ve öğle yemeği için ara verildi.

Prof. Dr. Mustafa Fayda başkanlığında gerçekleştirilen üçüncü oturumda ilk tebliğ Doç. Dr. Mehmet Akbaş tarafından "Sahabenin Cezîre/Diyarbakır Bölgesine Yerleşimi” başlığıyla sunuldu. Şam bölgesinin hâkimiyet altına alınmasından sonra Fırat-Dicle havzasının kuzeyine, 
Cezîre’ye doğru yönelen İslâm ordularının içerisinde pek çok sahabînin yer aldığını aktaran Akbaş, bu sahabîlerin bir kısmının bu bölgede şehit düştüğünü de ekledi. Oturumun ikinci tebliğini slâyt eşliğinde sunan Prof. Dr. Mustafa Zeki Terzi, “İlk Dönem İslam Fetih Siyaseti” başlıklı tebS liğinde fethin kavramsal çerçevesini çizdikten sonra, ayetler 1şı̆̆ında İslâm'da savaş, cihat, fetih ve barış anlayışını izah etti. Daha sonra meselenin hukuki boyutuna değinerek ilk dönem İslam fetih hareketlerinin temel niteliklerini özetleyen Terzi, hukuka ve ahlaka uygun savaş ve barış stratejilerinin takip edildiği, harekâtın İslâm’ı kılıç zoruyla yaymaktan uzak elde edilen sosyal durumu devam ettirmeye yönelik savunma amacı güttüğü, fethedilen yerlerde zimmet hukuku çerçevesinde kamu yararına bir politika takip edildiği neticesine vardığını ifade ederek tebliğini tamamladi.

Prof. Dr. Ahmet Önkal moderatörlüğündeki dördüncü oturumda "Cezîre Fatihi: Iyâd b. Ğanm” başlığıyla ilk tebliği Prof. Dr. Adem Apak sundu. Hudeybiye Antlaşmasından önce müslüman olan ve Rasulullah (s.a.s.) ile bütün gazvelere iştirak eden Iyâd b. Ğanm’ın hayatını ve cihad iştiyakını işleyen Apak, komutan olarak bulunduğu bölgeleri de belirtti. Ebû Ubeyde b. Cerrah tarafından süvari birlikleri komutanı olarak atanan Iyâd b. Ğanm’ın Ruha Anlaşmasını hayata geçirerek Ruha (Urfa) şehrini teslim aldığını ve Cezire’nin tamamına yakınını İslâm topraklarına kattığını anlatan Apak, sahabînin Şam’a dönüş yolunda Humus’ta vefat ederek Halid b. Velid'in yanına defnedildiğini ve yakınları Âmid'de kalan sahabînin soyundan Ebû Eyyûb ailesinin neşet ettiğini de ekledi. Sempozyumun son tebliği ise Doç. Dr. Salih Pay tarafından arz edildi. "Diyarbakır Fetihlerinde İlk Müslümanlardan Saîd b. Zeyd” başlıklı tebliğinde Pay, kaynaklarda hanîf bir ailede yetiştiği ifade edilen, küçük yaşta müslüman olan ve aşere-yi mübeşşere arasında ismi sayılan bu sahabînin hayatına dair bilgiler verdi. Cihadı yönetime tercih eden Saîd b. Zeyd'in Şam bölgesi genel komutanı Ebû Ubeyde b. Cerrah tarafından piyade komutanı olarak tayin edildiğini belirten Pay, Cezîre fethinde şehri kuşatan komutanlar arasında bulunduğunu da ekledi.

Tebliğlerin sona ermesiyle değerlendirme oturumuna geçildi. Prof. Dr. Mustafa Fayda, Prof. Dr. Mustafa S. Küçükaşçı, Prof. Dr. Nesimi Yazıcı, Prof. Dr. Mehmet Ali Kapar, Dr. Mustafa Sarıbıyık ve Diyarbakır Vali Yardımcısı Ahmet Dalkıran’ın iştirak ettiği oturuma Prof. Dr. Mehmet Şeker başkanlık etti. Sempozyumun önemine vurgu yapılan ve tebliğlerin değerlendirmelerinin yapıldığı oturumla program hitama erdirilerek akşam yemeği için hareket edildi.

Sempozyum akşamı gerçekleştirilen XI. İslam Tarihi Anabilim Dalları Koordinasyon Toplantısı iki oturum şeklinde icra edildi. İlk oturumda Prof. Dr. Şefaettin Severcan başkanlığında İlâhiyat Fakültelerinde Siyer müfredatı etüt edildi. Prof. Dr. Adnan Demircan ile Doç. Dr. ŞaP ban Öz yedi ünite şeklinde düzenledikleri ve on dört haftalık olması planlanan müfredatı, toplantı katılımcılarının dikkatine sundular. Tebliği izleyen müzakereler neticesinde hazırlanan müfredatın gelen eleştiri, teklif ve katkılarla yeniden şekillendirilmesi kararıyla oturum hitam buldu.

Toplantının Prof. Dr. Münir Atalar moderatörlüğünde gerçekleştirilen ikinci ve son oturumunda Prof. Dr. Mehmet Çelik Fen-Edebiyat Fakültelerindeki İslâm Tarihi Programını Celal Bayar Üniversitesi örneği üzerinden anlattı. Tarih bölümünde İslâm tarih ve medeniyetine yeterince yer verilmediğini belirten Çelik, müfredatta bu kabilden derslere ciddi derecede ihtiyaç olduğunu 
ifade etti. Tebliğin devamındaki müzakerelerden sonra geç saatlere kadar sürmüş olan toplantı geleneksel şekilde katılımcıların kendilerini tanıtmaları ile sona erdi.

Sempozyum sonrasındaki iki gün kültür gezilerine tahsis edildi. 24 Mayıs Cumartesi günü Mardin gezisi kapsamında Dara antik kenti, Kasımiye medresesi, Mardin Ulu Cami, Deyru’zZa'ferân, Midyat ve Hasankeyf rehberler eşliğinde gezildi. Diyarbakır’a tahsis edilen Pazar gününe ise Eğil'deki Peygamber türbelerinin ziyareti ile başlandı. Baraj kenarındaki dinlenceden sonra Diyarbakır merkeze dönülerek Hz. Süleyman Camii ve 27 sahabe türbesine geçildi. İç kale, dört ayaklı minare, Ulu Cami ve Hasan Paşa Hanı’nın da görülmesiyle program sona erdi. 